\title{
Derivatives of monoglycerides as apoptotic agents in T-cells
}

\author{
F Philippoussis ${ }^{1,2,3}$, E Przybytkowski ${ }^{2}$, M Fortin ${ }^{1,2}$, C Arguin ${ }^{1}$, \\ SV Pande ${ }^{2}$, A-M Steff ${ }^{1,2}$ and P Hugo, ${ }^{\star, 1,2,3}$, \\ 1 PROCREA BioSciences Inc., Division of Research Development, 6100 \\ Royalmount, Montréal, Québec, Canada, H4P 2R2 \\ 2 Institut de Recherches Cliniques de Montréal, 110 avenue des Pins Ouest, \\ Montréal, Québec, Canada, H2W 1 R7 \\ ${ }^{3}$ Department of Microbiology and Immunology, McGill University, 3775 \\ University Street, Montréal, Québec, Canada, H3A 2B4 \\ * Corresponding author: P Hugo, PROCREA BioSciences Inc., Division of \\ Research Development, 6100 Royalmount, Montréal, Québec, Canada, H4P \\ 2R2. Tel: 514-496-5282; Fax: 514-496-5288; E-mail: phugo@procrea.qc.ca
}

Received 22.2.01; revised 1.6.01; accepted 12.6.01

Edited by $\mathrm{G}$ Salvesen

\begin{abstract}
Recently, lipids have received considerable attention for their potential to induce apoptosis when added exogenously to cells. In this study, we directly demonstrate that murine T-cells undergo rapid apoptosis following treatment with various forms of monoglycerides, which are a family of naturally occurring lipids consisting of a single fatty acid moiety attached to a glycerol backbone. The potency of these lipids varied depending on their chemical structure, whereas glycerol backbone or corresponding fatty acids alone were ineffective. Moreover, monoglyceride-mediated apoptosis was suppressed either by $\mathrm{Bcl}-2$ overexpression, treatment with a broad inhibitor of caspases, or RNA and protein synthesis inhibitors. In addition, treatment of cells with derivatives of monoglycerides induced a calcium flux, which could be inhibited by both extracellular (EGTA) or intracellular (EGTA-AM) calcium chelators. To our knowledge, this is the first report demonstrating a role for derivatives of monoglycerides as inducers of apoptosis in mammalian cells. Cell Death and Differentiation (2001) 8, 1103-1112.
\end{abstract}

Keywords: apoptosis; lipids; monoglycerides; thymocytes; cell death

Abbreviations: AMC, aminomethylcoumarin; DAG, diacylglycerol; $\mathrm{DiOC}_{6}(3), 3,3$-dihexyloxacarbocyanine iodide; EGFP, enhanced green fluorescent protein; FCS, fetal calf serum; FITC, fluorescein isothiocyanate; $\mathrm{mAb}$, monoclonal antibody; MC540, merocyanin540; MG, monoglyceride; $\Delta \Psi_{\mathrm{m}}$, mitochondrial transmembrane potential; PBS, phosphate buffered saline; PI, propidium iodide; PS, phosphatidylserine; ROS, reactive oxygen species; TCR, T cell receptor; TUNEL, TdT-dependent dUTP-biotin nick end-labeling; zVAD-fmk, N-benzyloxycarbonyl-Val-Ala-Asp-fluoromethylketone

\section{Introduction}

Apoptosis, or programmed cell death, is a naturally occurring process of cell 'suicide' essential for the development and maintenance of tissue homeostasis in multicellular organisms. ${ }^{1,2}$ For instance, it is responsible for eliminating cells that have been either overproduced, improperly developed or genetically damaged. It is well recognized that deregulation of the apoptotic pathway can be involved in the pathogenesis of a variety of diseases such as cancer, AIDS, and neurodegenerative disorders. ${ }^{1}$ Thus, it is critical to improve our understanding of the mechanisms regulating apoptosis and to identify new pro- and anti-apoptotic stimuli in order to better design specific therapies.

A number of apoptotic stimuli have been identified, such as ligation of surface receptors (e.g. members of the tumor necrosis factor receptor family, and CD45), ${ }^{3-6}$ ligation of intracellular receptors (e.g. glucocorticoid receptors), ${ }^{7}$ and exposure to many environmental stresses (e.g. oxidative stress, ultraviolet and $\gamma$-irradiation).$^{8-13}$ Furthermore, in recent years, lipid derivatives have received considerable attention for their potential to induce apoptosis when added exogenously to cells. Most notably, treatment of various cell types with ceramides or sphingosines have been shown to induce apoptosis. ${ }^{14,15}$ Addition of either GD3 ganglioside, ${ }^{16}$ or the alkyllysophospholipid edelfosine (1-O-octadecyl-2-Omethyl-rac-glycero-3-phosphocholine; ET-18-OCH3) ${ }^{17,18}$ to leukemic cells has also been reported to trigger apoptosis. Moreover, tributyrin, a triglyceride analog of the short chain fatty acid butyrate, was demonstrated to induce cell death in MCF-7 human mammary carcinoma cells. ${ }^{19}$ Also, lysophosphatidic acid has been shown to induce cell death in neural cells, ${ }^{20,21}$ and to bind to $G$ protein-coupled receptors of the endothelial differentiation gene family. ${ }^{22,23}$ Noteworthy, these endothelial differentiation gene family receptors display homology to the cannabinoid receptors, ${ }^{24,25}$ which bind lipidic cannabinoid ligands such as $\Delta^{9}$-tetrahydrocannabinol, anandamide, and 2-arachidonylglycerol. ${ }^{26-29}$ Recently, such cannabinoids were demonstrated to display pro-apoptotic activity and suggested to have anti-tumoral activity. ${ }^{30-36}$ Although these examples do not comprise an exhaustive list, they illustrate the potency of different lipid derivatives to induce apoptosis.

The monoglyceride (MG) family of lipids, consisting of a single fatty acid moiety (saturated or unsaturated) attached to a glycerol backbone, is much less characterized. ${ }^{37}$ Under normal physiological conditions, the total concentration of MGs ranges from 2 to $10 \mu \mathrm{M}$, whilst the combined concentration of 1-C16:0 and 1-C18:1 MGs, alone, can reach up to $4 \mu \mathrm{M}$ in specific tissues. ${ }^{37,38}$ However, there is no information on the local concentrations of MGs in defined microenvironments, and it is possible that they could be dramatically increased under pathological conditions as shown with other lipids. ${ }^{39,40}$ In light of the recent 
literature on the ability of lipid derivatives to induce cell death, our objective was to investigate the potential of MGs to induce apoptosis. In this study, we provide direct evidence that derivatives of MGs can rapidly induce apoptosis in mammalian cells (murine T-cells). We also report that MG-induced apoptosis involves the activation of caspases and can be inhibited by overexpression of $\mathrm{Bcl}-2$, or the addition of either RNA or protein synthesis inhibitors.

\section{Results}

\section{Induction of rapid cell death in thymocytes by selected monoglycerides}

To verify whether treatment of mammalian cells with MGs would induce cell death, we exposed freshly isolated immature $T$ cells (thymocytes) to various MG-derivatives. Given that MGs are a large family, we used several compounds that differ in the length of the fatty acid and the degree of unsaturation of the fatty acid attached to the glycerol backbone. Among the various saturated MGs tested, 1-C14:0 MG and 1-C16:0 MG molecules appeared to be the most potent inducers of cell death, while other saturated MGs such as 1-C10:0 MG, 1-C12:0 MG, and 1-C18:0 MG were less active or even inactive (1-C8:0 MG) (Figure 1). We also assessed whether the presence of an unsaturated fatty acid bound to the glycerol backbone would influence the potency of MGs to trigger cell death, and found that unsaturated MGs (1-C16:1 MG, 1-C18:1 MG, and 1-C18:2 MG) were even better inducers of cell death (Figure 1). Importantly, no cell death was found when thymocytes were incubated with the vehicle, the glycerol backbone, or the corresponding fatty acid moieties alone (Figure 1). Finally, we also tested diacylglycerols (DAGs), related compounds to MGs, and observed that whereas 1,2-C8:0 DAG was able to induce cell death, 1,2C18:1 DAG was not (Figure 1). This is in contrast to the potencies demonstrated with the corresponding MGs, as 1-

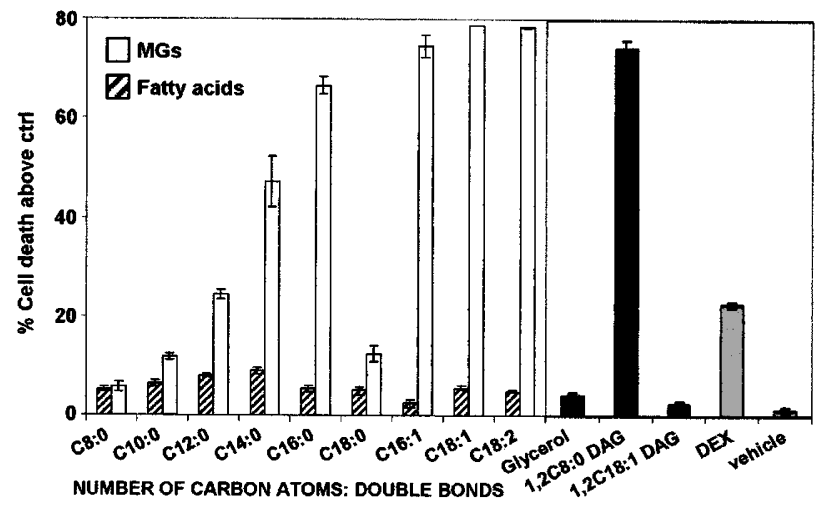

Figure 1 Derivatives of MGs cause cell death in thymocytes. C57BL/6 thymocytes were incubated with $80 \mu \mathrm{M}$ of either monoglycerides (MGs: white bars), fatty acids (hatched bars), diacylglycerols (DAGs: black bars), or glycerol (black bar). Refer to Materials and Methods for more details on lipids employed. As negative or positive control for cell death, cells were cultured with $1 \%$ ethanol (vehicle: gray bar) or $10^{-6} \mathrm{M}$ dexamethasone (DEX: gray bar), respectively. After $3 \mathrm{~h}$ stimulation the cells were stained with annexin VFITC. Results are shown as the mean percentage of cell death above control (medium only) \pm S.D. obtained from triplicates
C8:0 MG was a poor inducer, while 1-C18:1 MG was a strong death inducer (Figure 1). Although, at first glance, it appears that only long chain fatty acids containing compounds induce cell death, this is not the case as 1-C18:0 MG, 1-C20:0 MG, 1,2-C18:1 DAG, and long chain fatty acids alone are quite inefficient, while 1,2-C8:0 DAG, a short chain fatty acid containing compound, is a potent inducer of cell death (Figure 1 and not shown). Therefore, these results clearly demonstrate the ability of MGs to induce cell death in thymocytes and suggest a direct relationship between their chemical structure and their potency.

\section{Derivatives of MGs induce calcium fluxes}

Intracellular calcium flux has been reported to play a role in many pathways which lead to cell death. ${ }^{41,42}$ Also, exposure to many lipidic compounds, whether or not they induce cell death, have been shown to be capable of mobilizing intracellular calcium. ${ }^{22,30,43,44}$ We observed a good correlation between the ability of MGs and DAG to induce cell death and to mobilize calcium (Figure 2). Notably, the results obtained demonstrated differences in the kinetics as well as in the intensity of the calcium flux induced by various lipids tested (Figure 2 left panels). Cells treated with lipids in the presence of the extracellular calcium chelator, EGTA, displayed a dramatically reduced calcium flux (Figure 2 right panels). This calcium flux induction was further inhibited in the presence of intracellular calcium chelator, EGTA-AM (Figure 2 inset). Therefore, these results suggest that calcium from extracellular and intracellular source are involved in MGinduced calcium flux. As the potential of MGs to induce a calcium flux correlated well with their potential to induce cell death (Figures 1 and 2), experiments were performed to elucidate whether calcium was essential for the induction of cell death by MGs. The results demonstrated that inhibiting a MG-induced increase in calcium with either EGTA, medium without calcium, EGTA-AM, or various combinations of these conditions could not block cell death as measured by a decrease in mitochondrial transmembrane potential $\left(\Delta \Psi_{\mathrm{m}}\right)$, which is one hallmark of cells undergoing cell death (not shown). Hence, these results suggest that calcium mobilization might be involved, whilst not essential for cell death induced by MGs.

\section{Characteristics of MG-induced cell death}

Studies described hereafter were performed with 1-C18:1 $M G$, i.e. oleic acid bound to the glycerol backbone, because it is a predominant MG found in mammalian tissues. ${ }^{37}$ Our results demonstrated that thymocytes exposed to 1-C18:1 $M G$ underwent very rapid induction of cell death (within $30 \mathrm{~min}$ ) in a dose-dependent manner (Figure 3A,B). These results contrast the longer incubation times required for dexamethasone-mediated cell death, which is a well known inducer of apoptosis in thymocytes. 7,45

We later assessed if cell death induced by MGs involved apoptosis. Treatment of thymocytes with 1-C18:1 MG was shown to trigger a decrease in $\Delta \Psi_{\mathrm{m}}$ and was associated with the generation of reactive oxygen species (ROS) (Figure 4A). In addition, stimulation of thymocytes with 1- 


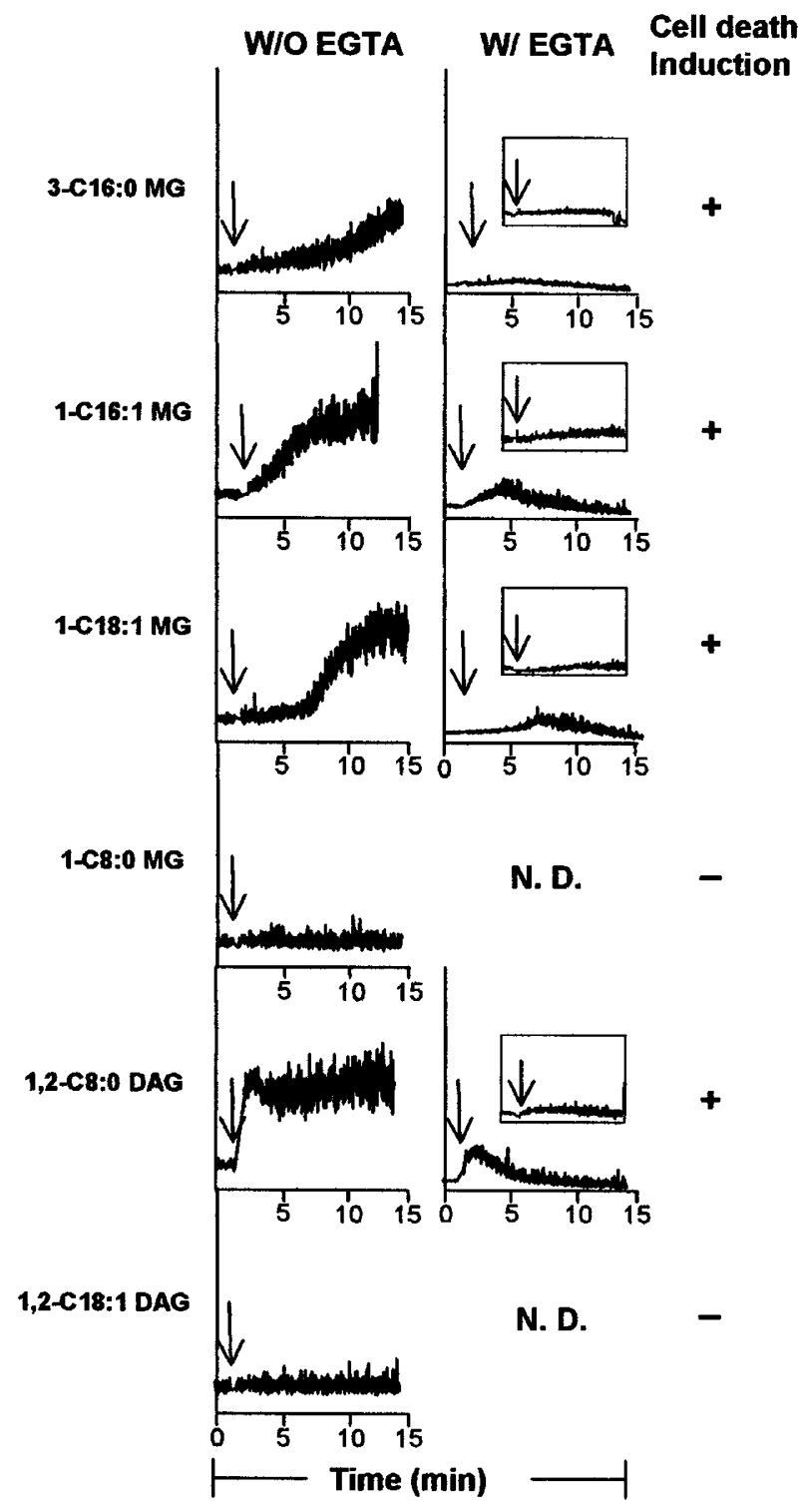

Figure 2 Derivatives of MGs induce a calcium flux which can be inhibited by calcium chelators. Thymocytes were incubated with the calcium indicator FLUO-3-AM, and later resuspended either in the absence (left panels) or presence of extracellular (10 mM EGTA: right panels) or cell permeable (200 $\mu$ M EGTA-AM: insets) calcium chelators. FLUO-3 fluorescence intensity was measured before and after treatment with various lipids (i.e. $100 \mu \mathrm{M} 3$ C16:0 MG, $60 \mu \mathrm{M}$ 1-C16:1 MG, $60 \mu \mathrm{M}$ 1-C18:1 MG, $100 \mu \mathrm{M}$ 1-C8:0 MG, $60 \mu \mathrm{M}$ 1,2-C8:0 DAG, and $100 \mu \mathrm{M}$ 1,2-C18:1 DAG) (15 min acquisition). Refer to Materials and Methods for more details on lipids employed. The arrow indicates the time of addition of the stimulus

C18:1 MG induced: externalization of phosphatidylserine (PS) residues; loosening of membrane phospholipids; cell shrinkage as observed by forward and side scatter profile using a flow cytometer, which detects size and granularity of cells, respectively; and ultimately DNA degradation as detected either by the TdT-dependent dUTP-biotin nick end-labeling (TUNEL) assay or the direct visualization of the characteristic DNA nucleosomal ladder (Figure 4A,B,C). Similar observations were made with cells cultured with

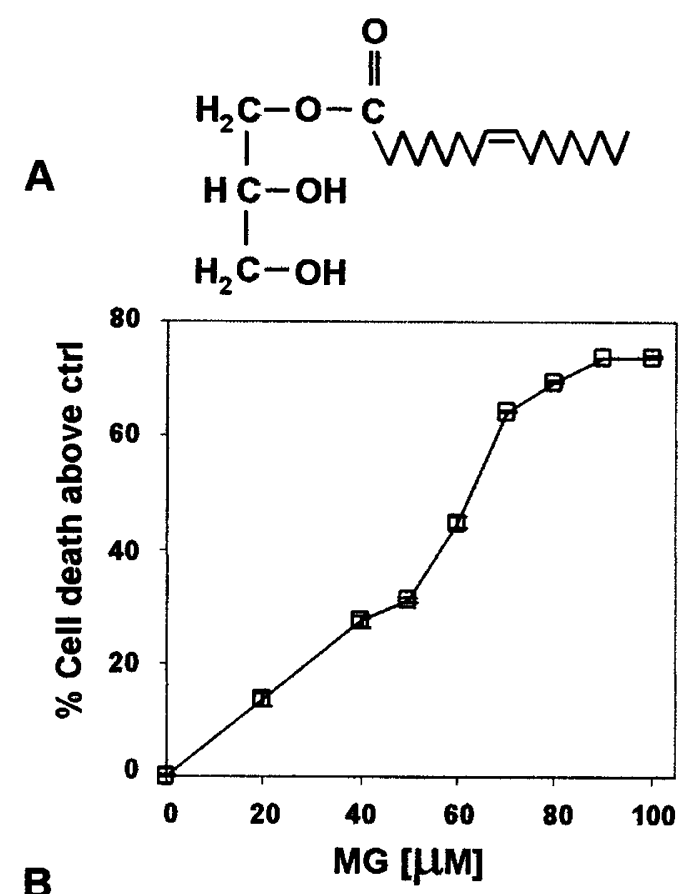

$\mathbf{B}$

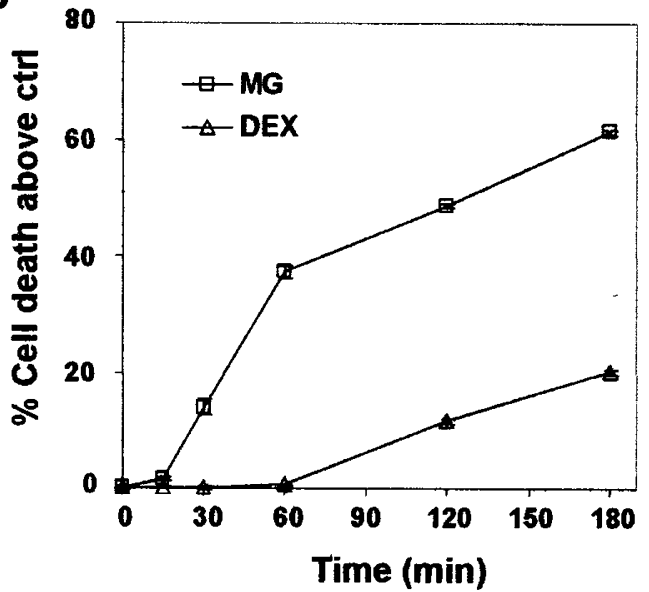

Figure $3 \mathrm{MG}$ induces rapid cell death in a dose response manner. (A) $\mathrm{C} 57 \mathrm{BL} / 6$ thymocytes were stimulated for $3 \mathrm{~h}$ with various concentrations of 1 C18:1 MG and stained with annexin V-FITC. (B) Thymocytes were cultured with either $60 \mu \mathrm{M}$ 1-C18:1 MG (MG: squares) or $10^{-6} \mathrm{M}$ dexamethasone (DEX: triangles). Cells were harvested after various time points and stained with annexin V-FITC. Results are shown as mean percentages of cell death above control $(1 \%$ ethanol $) \pm$ S.D. from triplicates

saturated 3-C16:0 MG and unsaturated 1-C16:1 MG (not shown). These results clearly indicate that exposure of thymocytes to MGs causes cell death through the induction of apoptosis.

Whereas some agents that induce apoptosis require de novo mRNA and protein synthesis (e.g. dexamethasone), others do not (e.g. Fas). ${ }^{2}$ 1-C18:1 MG-mediated cell death resembles the former class of apoptotic agents, as it was significantly decreased in the presence of either actinomycin D or cycloheximide, RNA or protein synthesis inhibitors, respectively (Figure 5 ).

We next investigated whether MG-induced apoptosis was also dependent on caspases. The decrease in $\Delta \Psi_{\mathrm{m}}$ 


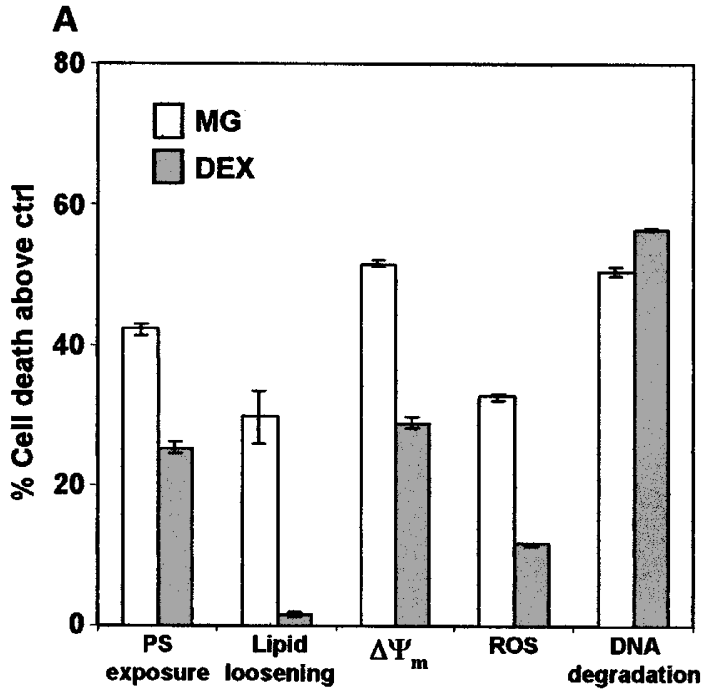

B

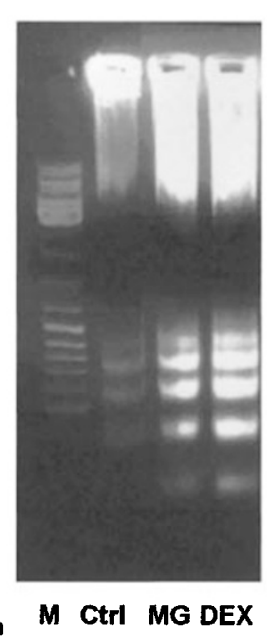

C
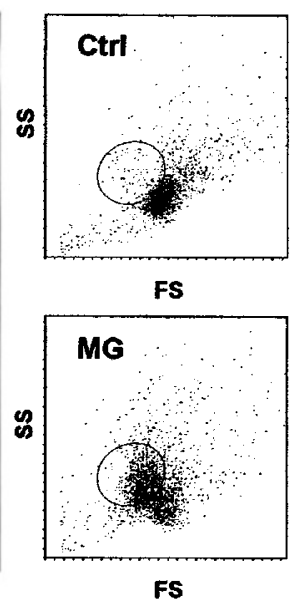

FS

Figure $4 \mathrm{MG}$ induces apoptosis in thymocytes. Thymocytes were incubated with $60 \mu \mathrm{M}$ 1-C18:1 MG (MG). As controls, cells were cultured with $1 \%$ ethanol (ctrl) or in the presence of $10^{-6} \mathrm{M}$ dexamethasone (DEX). (A) The cells were labeled after $3 \mathrm{~h}$ stimulation with either annexin V-FITC (PS exposure), MC540 (lipid loosening), $\mathrm{DiOC}_{6}(3)\left(\Delta \Psi_{\mathrm{m}}\right)$, dihydroethidine (ROS), or with $6 \mathrm{~h}$ with a TUNEL reaction (DNA degradation). Results are shown as mean percentages of cell death above control (1\% ethanol) \pm S.D. from triplicates. (B) DNA degradation was also assessed after a $6 \mathrm{~h}$ stimulation by the detection of an apoptotic DNA ladder. (C) Physical changes of cells such as cell shrinkage was detected using the forward and side scatter profile by flow cytometry, which detects size and granularity of cells, respectively

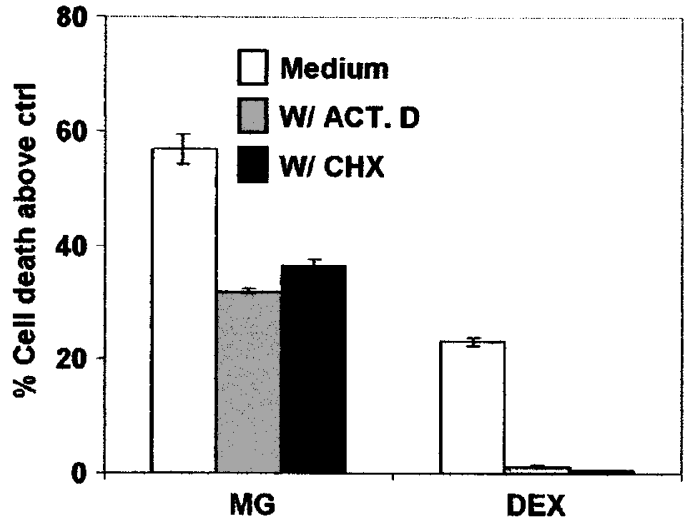

Figure 5 RNA and protein synthesis inhibitors, actinomycin D and cycloheximide, inhibit MG-induced apoptosis. Thymocytes were incubated with $1 \%$ ethanol (ctrl), $60 \mu \mathrm{M} 1-\mathrm{C} 18: 1 \mathrm{MG}$ (MG) or $10^{-6} \mathrm{M}$ dexamethasone (DEX) either in the absence (Medium) or in the presence of $5 \mu \mathrm{g} / \mathrm{m}$ actinomycin D (W/ACT.D) or $50 \mu \mathrm{g} / \mathrm{ml}$ cycloheximide (W/CHX). The cells were labeled after $3 \mathrm{~h}$ stimulation with annexin V-FITC. Results are shown as mean percentages of cell death above control $(1 \%$ ethanol $) \pm S$ S.D. from triplicates

and PS exposure induced by 1-C18:1 MG was inhibited with the addition of z-VAD-fmk, a broad inhibitor of caspases, thus suggesting that caspases are activated during MG-induced apoptosis (Figure 6A). Indeed, cleavage of the effector caspase, caspase 3, was found after 1C18:1 MG treatment, a process that could also be inhibited with the addition of z-VAD-fmk (Figure 6B). Given that zVAD-fmk was able to inhibit the decrease in $\Delta \Psi_{\mathrm{m}}$ after 1C18:1 MG treatment, this suggested that initiator caspases were involved in 1-C18:1 MG-induced cell death. Therefore, we investigated a possible role for the initiator caspases 8 and 9. We observed that caspase 8 was not cleaved after 1-C18:1 MG treatment as measured by Western blot, although it was cleaved in our positive control (i.e. murine $\mathrm{T}$-cell hybridomas induced to undergo $\mathrm{T}$ cell activationinduced cell death which involves Fas/Fas ligand interactions and leads to caspase 8 activation) ${ }^{46-48}$ (Figure 6C). However, activation of caspases with LEHD substrate specificity (which caspase 9 belongs to) was observed after 1-C18:1 MG treatment using two different caspase activity assay kits (Figure 6D,E). Finally, kinetic studies were conducted for caspases with DEVD- (which caspase 3 belongs to) and LEHD-ase activity and our results demonstrated that thymocytes treated with 1-C18:1 MG activated caspases very rapidly (within $15 \mathrm{~min}$ ), with a slightly higher percentage of cells displaying LEHD-ase activity at 15 min than DEVD-ase activity (Figure 6E). These results contrast the longer incubation times required for dexamethasone-induced caspase activation (Figure 6E), and correlate well with the kinetics of cell death induction (Figure 3). Together, these findings suggest that caspase 3, most likely caspase 9 , and not caspase 8 are activated in 1-C18:1 MG-induced apoptosis.

To further understand the mechanism of apoptosis induced by MGs, we assessed the involvement of $\mathrm{Bcl}-2$, which is a well known inhibitor of apoptosis, ${ }^{49,50}$ in MGmediated cell death. Thymocytes from Bcl-2 transgenic mice were less sensitive to $M G$ treatment than were thymocytes from wild-type mice (Figure 7A). This protective effect was even more pronounced in murine T-cell hybridoma (D011.10) cells that overexpress Bcl-2 (Figure 7B). Together, the data indicate that MG-induced cell death involves changes characteristic of apoptosis, through a pathway involving caspases, which can be inhibited by RNA or protein synthesis inhibitors, or by Bcl-2 overexpression. 
A
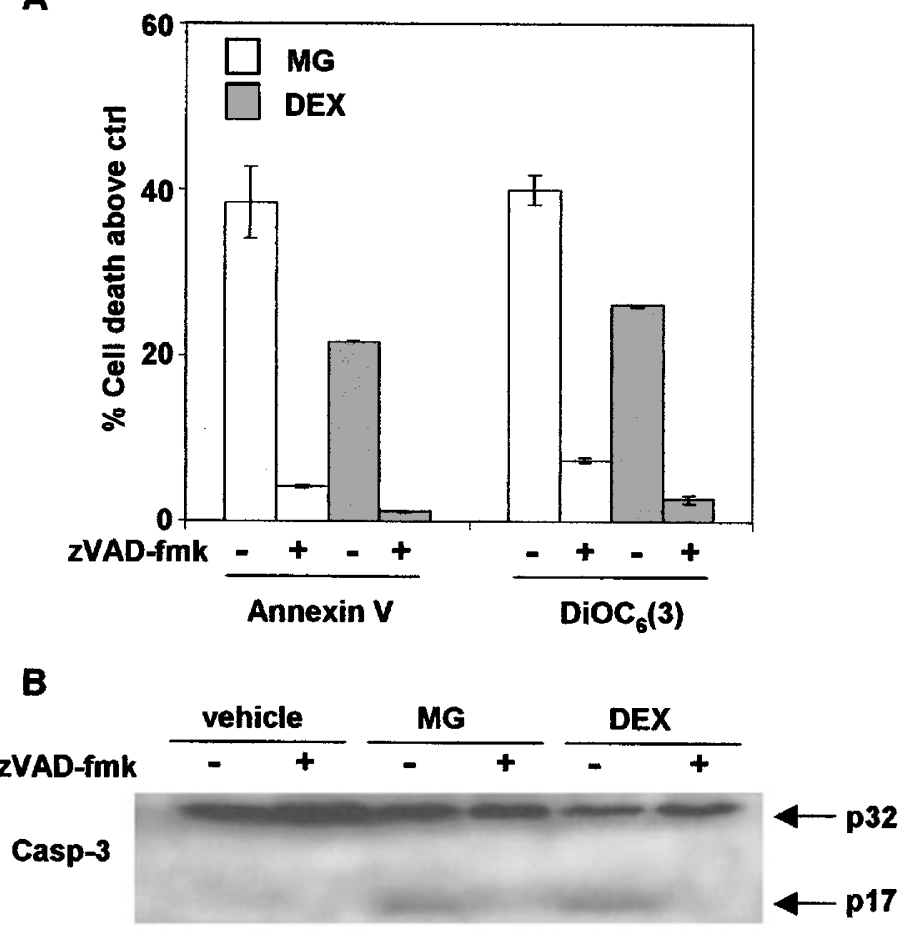

C

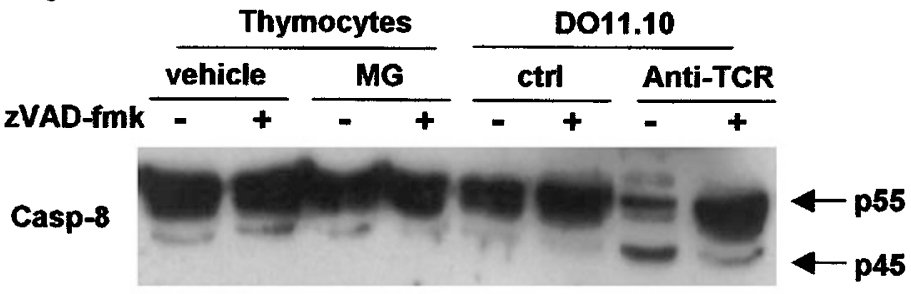

D

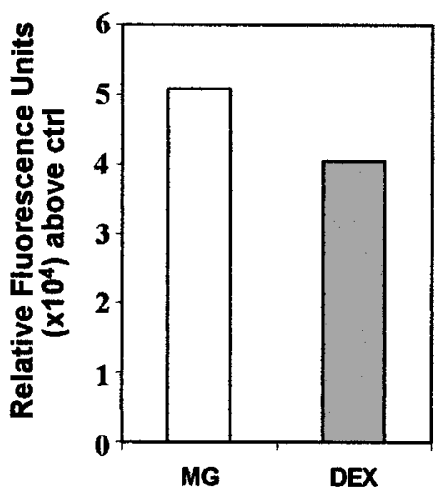

E
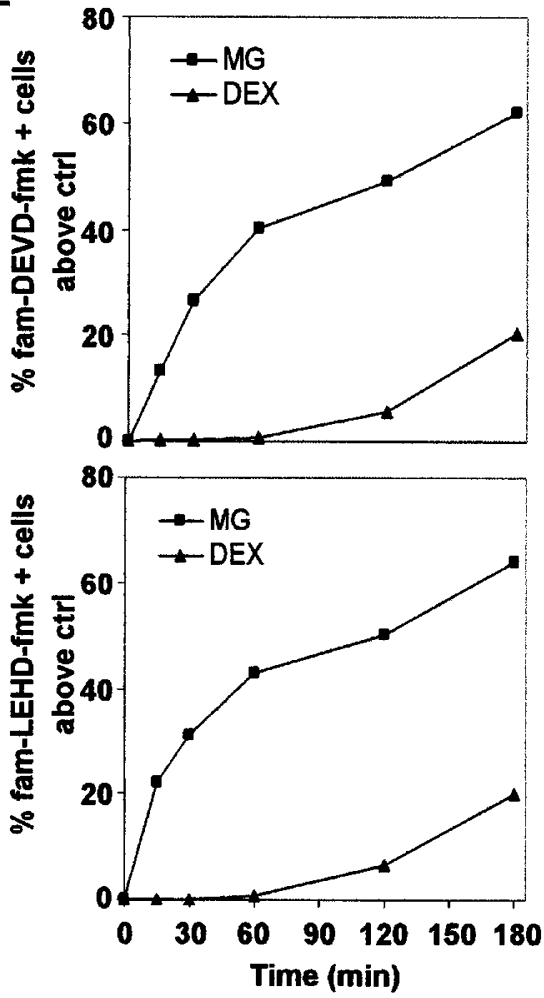

Figure 6 Caspases are activated in MG-mediated apoptosis. (A) Thymocytes were incubated with $60 \mu \mathrm{M}$ 1-C18:1 MG (MG), or $10^{-6} \mathrm{M}$ dexamethasone (DEX) either in the absence $(-)$ or presence $(+)$ of $50 \mu \mathrm{M}$ zVAD-fmk. Cells were incubated with zVAD-fmk $15 \mathrm{~min}$ before the addition of the stimulus. After $3 \mathrm{~h}$ incubation, cells were either stained with annexin V-FITC or DiOC 6 (3). Results are shown as mean percentages of cell death above control $(1 \%$ ethanol) \pm S.D. from triplicates. (B) Cells were treated as in (A) but cell lysates were prepared and analyzed by Western blot using an anti-caspase 3 antibody. This antibody recognizes both the unprocessed $(32 \mathrm{kDa})$ and the processed $(17 \mathrm{kDa})$ fragments of caspase 3 (depicted by the arrows). (C) Thymocytes were treated as in (A) and DO11.10 cells were incubated for $16 \mathrm{~h}$ with medium or $1 \mu \mathrm{g} / \mathrm{ml}$ of anti-TCR $\beta \mathrm{mAb}$ (H57-597) (positive control for caspase 8 cleavage) either in the absence (-) or presence (+) of $50 \mu \mathrm{M}$ zVAD-fmk. Western blot was performed with an anti-caspase 8 antibody. This antibody recognizes both the unprocessed (55 kDa) and the partially processed $(45 \mathrm{kDa})$ fragments of caspase 8 (depicted by the arrows). (D) Thymocytes were treated with $60 \mu \mathrm{M} 1-\mathrm{C} 18: 1 \mathrm{MG}(\mathrm{MG})$ or $10^{-6} \mathrm{M}$ dexamethasone (DEX) and cell extracts were assayed with the fluorogenic substrate LEHD-AMC. Data are expressed in relative fluorescence units above control ( $1 \%$ ethanol). (E) Thymocytes were cultured with either $60 \mu \mathrm{M}$ 1-C18:1 MG (MG: squares) or $10^{-6} \mathrm{M}$ dexamethasone (DEX: triangles). Cells were harvested after various time points and stained with either fam-DEVD-fmk (top graph) of fam-LEHD-fmk (lower graph). Results are shown as fam-DEVD-fmk (top graph) or fam-LEHD-fmk (lower graph) positive cells above control ( $1 \%$ ethanol)

\section{Discussion}

In the present study, we identified derivatives of MGs as novel apoptotic agents in mammalian cells. We noted that $T$ cells treated with several types of MGs underwent rapid apoptosis in a dose-dependent manner. This property of MGs appears to be specific, since treatment with either glycerol or the corresponding fatty acids did not induce cell death. Importantly, concentrations at which MGs were found to cause apoptosis were in the same range, and frequently lower than those used with other classes of pro-apoptotic lipids. For instance, ceramide, sphingosine, GD3 ganglioside, palmitic 
A
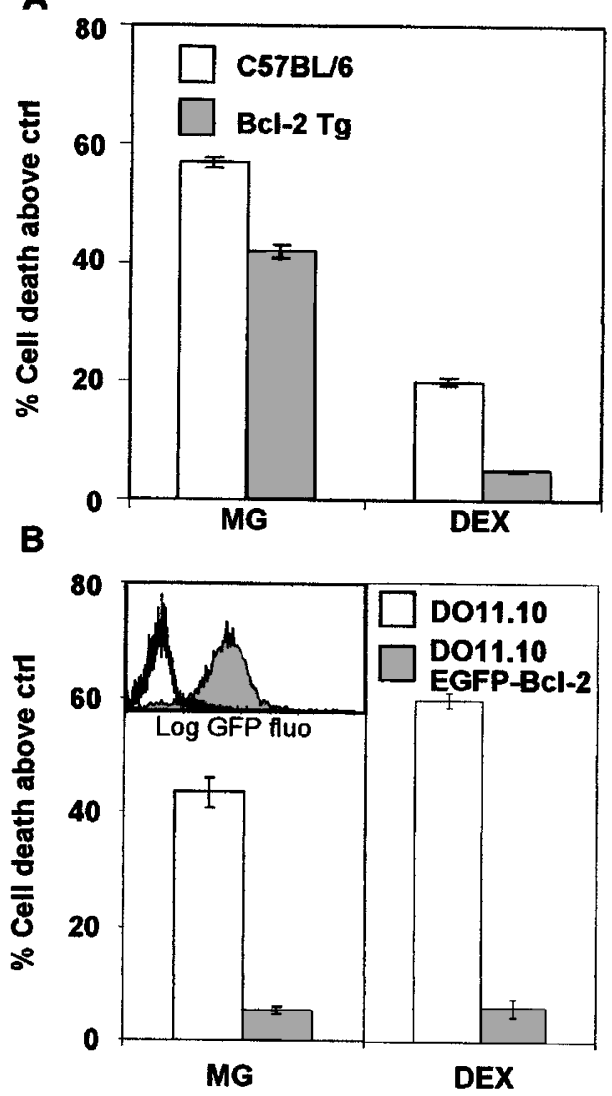

Figure 7 BCL-2 overexpression inhibits MG-mediated cell death. (A) Thymocytes from $\mathrm{C} 57 \mathrm{BL} / 6$ (white bars) or $\mathrm{Bcl}-2$ transgenic (gray bars) mice were incubated for $3 \mathrm{~h}$ with either $60 \mu \mathrm{M}$ 1-C18:1 MG (MG) or $10^{-6} \mathrm{M}$ dexamethasone (DEX) and stained with annexin V-FITC. (B) DO11.10 (white) or D011.10 EGFP-Bcl-2 (gray) cells were incubated for $3 \mathrm{~h}$ with $60 \mu \mathrm{M}$ 1-C18:1 $\mathrm{MG}$ or $16 \mathrm{~h}$ with $10^{-7} \mathrm{M}$ dexamethasone and stained with MC540. EGFP expression in D011.10 (white histogram) and D011.10 EGFP-Bcl-2 (gray histogram) cells is depicted in the insets. Results are shown as mean percentages of cell death above control $(1 \%$ ethanol $) \pm$ S.D. from triplicates

acid, arachidonic acid, and tributyrin have been studied, in terms of their pro-apoptotic activities, mainly with concentrations ranging from 20 to $500 \mu \mathrm{M},{ }^{15,16,51-55}$ and even up to $5 \mathrm{mM} .{ }^{19}$ Moreover, under normal physiological conditions, the total concentration of MGs are in the lower micromolar range in specific tissues. ${ }^{37,38}$ It is conceivable that under certain stress conditions, MG levels could locally increase transiently as shown with other lipids. ${ }^{14,16}$ However, this remains to be investigated and is beyond the scope of this study.

Calcium has been implicated in the regulation of apoptosis in a variety of studies. ${ }^{41,42}$ For instance, it has been shown that the disruption of calcium homeostasis can trigger apoptosis, ${ }^{56}$ that some apoptotic pathways lead to an increase in the concentration of intracellular calcium, ${ }^{57}$ and that calcium chelators inhibit cell death in some systems, ${ }^{58}$ but not all. ${ }^{34,59,60}$ We observed that MGs induce a sustained elevation of intracellular calcium which implicates both a flux from extracellular source as well as mobilization of intracellular stores (Figure 2). Of interest are the distinct kinetics and intensity in intracellular calcium rises seen with the different MGs. A sustained increase in calcium flux has been observed by other apoptotic stimuli ${ }^{34}$ and it has been suggested that prolonged increases in calcium are generally toxic. ${ }^{61}$ Nevertheless, while derivatives of MGs induce a calcium flux, they do not appear, under the conditions tested, to be essential for cell death induction, as also shown with other apoptotic experimental systems. ${ }^{34,59,60,62}$

The exact mechanism by which MGs induce apoptosis is currently unknown. It is conceivable that MGs could simply induce cell death through a non-specific effect. For instance, MGs could intercalate into the cytoplasmic membrane altering its fluidity and permeability, as suggested for other lipids, ${ }^{53}$ which could lead to apoptosis. However, we do not favor this possibility because this property increases with the lipid melting point. ${ }^{53}$ In contrast, in our study, unsaturated MGs (lower melting point) displayed, in general, greater or equal potency to trigger apoptosis than their saturated counterparts (higher melting point) (Figure 1). In addition, the potency of MGs to induce apoptosis varied depending on their chemical structure and, in fact, 1-C8:0 MG had no effect while 1-C18:1 MG was highly potent (Figure 1). Nevertheless, all the corresponding fatty acids tested, used at the same concentrations as MGs, were unable to induce cell death (Figure 1). Also, defined subsets of early T-cell precursors (CD4 ${ }^{-} \mathrm{CD}^{-}$thymocytes) and mature $\mathrm{T}$ cells are relatively resistant to the effect of MGs as compared to the immature subset $\left(\mathrm{CD}^{+} \mathrm{CD}^{+}\right.$thymocytes), thus showing that susceptibility to the compound is modulated during $\mathrm{T}$ cell differentiation (manuscript in preparation). Moreover, MG-induced cell death requires de novo protein synthesis and can be blocked by either Bcl-2 overexpression or by the addition of z-VAD-fmk. Finally, we believe that MGs do not cause cell death through a 'detergent effect' (i.e. disrupting the cell membrane and causing rapid cytolysis), given that MGs do not lyse sheep red blood cells (unpublished observations), MG-induced cell death requires de novo mRNA and protein synthesis, and MG-induced cell death displays cellular specificity which is not the case with other amphiphilic detergents. ${ }^{63-67}$

Alternatively, MGs used in this study could interact with membrane receptors to induce apoptosis. Supporting this notion, 2-arachidonyl-glycerol, a MG, has been shown to bind to cannabinoid receptors. ${ }^{28,29}$ Interestingly, it has been recently reported that cannabinoids have the potential to induce apoptosis and could even have anti-tumoral activity. ${ }^{30-36}$ In addition, lysophosphatidic acid, which resembles MGs, and can itself be converted to MGs, ${ }^{68}$ acts through cell surface $\mathrm{G}$ protein-coupled receptors of the endothelial differentiation gene family. ${ }^{22}$ However, preliminary results from our laboratory indicate that pertussis toxin, an inhibitor of $\mathrm{G}$ protein-coupled receptors, is unable to inhibit MG-induced cell death (unpublished observations). Finally, the study of lipids and their mechanism of actions is hindered due to their amphipathic nature which allows them to bind non-specifically ${ }^{69}$ and, in fact, the mechanism underlying the action of more extensively studied lipids is still elusive. ${ }^{18,70-72}$ 
Regardless of the possible upstream mechanisms, we have shown that treatment with MGs rapidly triggers a cascade of events, such as a drop in $\Delta \Psi_{\mathrm{m}}$, ROS production, membrane alterations, caspase activation, and finally DNA degradation. In fact, activation of caspases parallels well with cell death induction. Whereas caspases are activated very rapidly (within $15 \mathrm{~min}$ ), even before cell death, after MG treatment, dexamethasone requires longer incubation times to activate caspases and to induce cell death (Figures 3 and 6 ). In addition, the rapid caspase activation induced by MGs culminates in cellular apoptosis, which can be inhibited by $\mathrm{Bcl}-2$ overexpression. Our findings also indicate that inhibitors of RNA and protein synthesis could reduce cell death induced by 1-C18:1 MG (Figure 5), suggesting that 1-C18:1 MG-induced apoptosis relies on target molecules.

This study demonstrates that treatment with derivatives of MGs can induce apoptosis in mammalian cells, suggesting that MGs could represent putative anti-tumor agents. For instance, ether lipids, which have some structural similarity to naturally occurring MGs, have been extensively studied for their anti-cancer activity. ${ }^{73}$ Among these, edelfosine, a synthetic analog of lysophosphatidylcholine which induces apoptosis, ${ }^{17,18}$ has become the prototype for ether lipid anti-tumor drugs, although its mechanism of action is still unclear. ${ }^{18,71,72}$ Furthermore, several years ago, Kato et al. ${ }^{74}$ reported in vivo anti-tumor activity for MGs, where treatment of mice with MGs significantly inhibited the growth of intraperitoneally implanted Ehrlich ascites tumors, without being toxic for the host. However, the mechanism of MG-mediated tumor growth inhibition was totally unknown and could, theoretically, have been attributed to a direct cytotoxic or cytostatic activity towards the tumor cells or, yet, to an indirect effect on the host immune system, increasing the animal response against the tumor cells. Results presented in this study support a direct anti-tumor activity of MGs. Indeed, preliminary results from our laboratory demonstrate that MGs can induce cell death in leukemic cell lines (manuscript in preparation). Altogether, these findings suggest that MGs could represent candidate therapeutic agents in the treatment of pathologies such as leukemia.

\section{Material and Methods}

\section{Mice}

C57BL/6 mice were purchased from the Jackson Laboratory (Bar Harbor, ME, USA) and $\mathrm{Bcl}-2$ transgenic mice were kindly provided by Dr. P Jolicoeur (Institut de Recherches Cliniques de Montréal, QC, Canada). All the mice were bred and housed either at the Institut de Recherches Cliniques de Montréal specific pathogen free animal facility or at the Biotechnology Research Institute animal facility, according to institutional guidelines.

\section{Cells and constructs}

Immature T cells (i.e. thymocytes) were obtained from 3-8-week-old mice and plated at $4 \times 10^{6}$ cells $/ \mathrm{ml}$. DO11.10 murine T-cell hybridoma cells ${ }^{75}$ were plated at either $1.6 \times 10^{6} \mathrm{cells} / \mathrm{ml}$ or $4 \times 10^{5} \mathrm{cells} / \mathrm{ml}$ depending on the experiment. D011.10 overexpressing the Bcl-2Enhanced Green Fluorescent Protein (EGFP) (referred as EGFP-Bcl-2 cells) were obtained by electroporation of D011.10 cells with an EGFP-Bcl-2 fusion construct. This construct was produced by subcloning the human Bcl-2 cDNA (GeneBank \# M14745) 3' of the EGFP coding region of the pEGFP-C3 plasmid vector $(B g / l / E c o R I$ sites) (Clontech, Palo Alto, CA, USA). Stable transfectants were obtained after G418 selection (Mediatech, Herndon, VI, USA) and EGFP-Bcl-2 expression was confirmed by flow cytometry. All experiments were conducted in RPMl 1640 medium (Wisent Inc., StBruno, QC, Canada) supplemented with $5 \%$ fetal calf serum (FCS: Montréal Biotech Inc., Kirkland, QC, Canada), at $37^{\circ} \mathrm{C}$ and $5 \% \mathrm{CO}_{2}$.

\section{Drug treatment}

The lipid derivatives used were: caprylic acid (C8:0), 1-monocapryloylglycerol (1-C8:0), capric acid (C10:0), 1-monodecanoyl-glycerol (1C10:0), lauric acid (C12:0), 1-monolauroyl-glycerol (1-c12:0), myristic acid (C14:0), 1-monomyristoyl-glycerol (1-C14:0), palmitic acid (C16:0), 1-monopalmitoyl-glycerol (1-C16:0), 3-monopalmitoyl-glycerol (3-C16:0), stearic acid (C18:0), 1-monostearoyl-glycerol (1-C18:0), palmitoleic acid (C16:1 [cis] 9), 1-monopalmitoleyl-glycerol (1-C16:1 [cis] 9), oleic acid (C18:1), 1-monooleoyl-glycerol (1-C18:1 [cis] 9), linoleic acid (C18:2 [cis, cis] 9,12), 1-monolinoleoyl-glycerol (1-C18:2 [cis,cis] 9,12), and 1,2-dioctanoyl-glycerol (1,2-C8:0), which were purchased from Sigma-Aldrich (Oakville, ON, Canada). Glycerol was from Fisher Scientific Co. (Montreal, QC, Canada) and 1,2-dioleoylglycerol (1,2-C18:1) from Biomol Research Laboratories, Inc. (Plymouth Meeting, PA, USA). All lipids were dissolved in $95 \%$ ethanol and stock solutions of $10 \mathrm{mM}$ were stored at $-20^{\circ} \mathrm{C}$. Before each experiment, stock solutions were left at room temperature for $10 \mathrm{~min}$, pre-warmed at $37^{\circ} \mathrm{C}$ for $30 \mathrm{~min}$, vortexed, and then dissolved in RPMI $1640-5 \%$ FCS pre-warmed at $37^{\circ} \mathrm{C}$ for $5 \mathrm{~min}$. The mixture was vigorously vortexed and added at the appropriate concentration. The final concentration of vehicle (ethanol) in cell suspension was $1 \% \mathrm{v} / \mathrm{v}$ or less. Controls with vehicle alone were included and were without effect on experiments. Noteworthy, to test for potential lack of solubility of the compounds, stock solutions were also subjected to both filtering through a $0.22 \mu \mathrm{m}$ membrane and ultracentrifugation at $100000 \times \mathrm{g}$ for $1 \mathrm{~h}$ in polyallomer tubes. Furthermore, compounds were also dissolved in DMSO and were subjected to the same type of filtering as above. Equivalent results were obtained for all conditions tested.

Dexamethasone (Sigma-Aldrich) was used at a final concentration of $10^{-6}$ or $10^{-7} \mathrm{M}$ for thymocytes or cell lines, respectively. When $\mathrm{T}$ cell receptor (TCR) cross-linking was used to induce apoptosis, $1 \mu \mathrm{g} /$ $\mathrm{ml}$ of anti-TCR $\beta$-chain monoclonal antibodies (mAbs), H57-597,76 were first immobilized on the bottom of 96-well Probind plates (Falcon, BD Biosciences, Oakville, ON, Canada) by a $2 \mathrm{~h}$ incubation at room temperature. zVAD-fmk (N-benzyloxycarbonyl-Val-Ala-Asp-fluoromethylketone: Kamiya Biomedical Co. Seattle, WA, USA) was dissolved in DMSO and added to cells at $50 \mu \mathrm{M} 15$ min before the addition of the apoptotic stimulus. Actinomycin D (Sigma-Aldrich) or cycloheximide (Sigma-Aldrich) were added at 5 or $50 \mu \mathrm{g} / \mathrm{ml}$, respectively.

\section{Intracellular calcium measurement}

Intracellular calcium flux was measured as described ${ }^{77}$ with some modifications. Cells, $5 \times 10^{5}$, were washed in RPMI 1640 medium supplemented with $0.1 \%$ BSA (ICN Biomedicals, Montreal, QC, Canada), and 25 mM HEPES pH 7.4 (Wisent) (RPMI/BSA medium). 
The cells were resuspended with $100 \mu \mathrm{l}$ RPMI/BSA medium supplemented with $3 \mu \mathrm{M}$ FLUO-3AM (Molecular Probes, Eugene, OR, USA), and incubated in the dark for $45 \mathrm{~min}$ at $37^{\circ} \mathrm{C}$ under $5 \%$ $\mathrm{CO}_{2}$. After washings in RPMI containing $5 \% \mathrm{FCS}$ and $25 \mathrm{mM} \mathrm{HEPES}$ $\mathrm{pH} 7.4$ (RPMI 5\%), the cells were resuspended in RPMI 5\%, or RPMI $5 \%$ supplemented with either $10 \mathrm{mM}$ EGTA (extracellular calcium chelator) (Sigma-Aldrich), or $200 \mu \mathrm{M}$ EGTA-AM (intracellular calcium chelator) (Calbiochem; San Diego, CA, USA). The samples were warmed to $37^{\circ} \mathrm{C}$ for $5 \mathrm{~min}$ before the beginning of the acquisition, and maintained at $37^{\circ} \mathrm{C}$ for the duration of the flow cytometric analysis. Unstimulated cells were analyzed for 1-2 min to establish baseline fluorescence levels, the stimulus was added, and acquisition was resumed for a total of $15 \mathrm{~min}$. Flow cytometric analysis were performed on a Coulter EPICS XL ${ }^{\circledR}$ flow cytometer (Beckman Coulter, Ville St-Laurent, QC, Canada) equipped with a $488 \mathrm{~nm}$ argon laser and the XL2 software. FLUO-3 fluorescence was measured at $525 \mathrm{~nm}$ and was plotted against time using the WinMDI ${ }^{\circledR}$ software (Dr. J Trotter, Scripps Research Institute, San Diego, CA, USA).

\section{Measurement of mitochondrial transmembrane potential and reactive oxygen species}

Mitochondrial transmembrane potential $\left(\Delta \Psi_{\mathrm{m}}\right)$ and reactive oxygen species (ROS) production were evaluated by the incorporation of the dye 3,3'-dihexyloxacarbocyanine iodide $\left(\mathrm{DiOC}_{6}(3)\right)$ and the conversion of dihydroethidine into ethidium, respectively. Briefly, after treatment, thymocytes were harvested and incubated in phosphate buffered saline (PBS) containing $40 \mathrm{nM} \mathrm{DiOC} 6$ (3) and $2 \mu \mathrm{M}$ dihydroethidine (Molecular Probes) for $15 \mathrm{~min}$ at $37^{\circ} \mathrm{C}$. Cells were washed and further incubated at $37^{\circ} \mathrm{C}$ for $30 \mathrm{~min}$ in PBS. After washing, cells were resuspended in PBS and propidium iodide (PI) (Sigma-Aldrich) was added at a final concentration of $10 \mu \mathrm{g} / \mathrm{ml}$. $\mathrm{DiOC}_{6}(3)$, ethidium and PI fluorescence were detected at 525, 575 and $670 \mathrm{~nm}$, respectively.

\section{Staining of membrane phospholipids}

Phosphatidylserine (PS) exposure was detected by the binding of Annexin V (BioDesign International, Kennebunk, ME, USA), as previously described. ${ }^{78}$ Briefly, after harvesting, thymocytes were washed and incubated in binding buffer (10 mM HEPES, $150 \mathrm{mM}$ $\mathrm{NaCl}, 5 \mathrm{mM} \mathrm{KCl}, 1 \mathrm{mM} \mathrm{MgCl}_{2}$, and $1.8 \mathrm{mM} \mathrm{CaCl}$ ) with fluorescein isothiocyanate (FITC)-conjugated Annexin $\mathrm{V}$, for $5 \mathrm{~min}$ at room temperature. Volume was adjusted to $500 \mu \mathrm{l}$ with binding buffer and PI was added at $10 \mu \mathrm{g} / \mathrm{ml}$. Loosening of phospholipid was detected with merocyanin-540 (MC540: Molecular Probes). Cells were resuspended in $100 \mu \mathrm{l}$ of PBS, $0.1 \%$ BSA containing $5 \mu \mathrm{g} / \mathrm{ml}$ MC540. The samples were incubated for $3 \mathrm{~min}$ at room temperature and resuspended in $400 \mu \mathrm{l}$ of PBS. Flow cytometric analysis was carried out with detectors at 525, 575, and $670 \mathrm{~nm}$ for Annexin VFITFC, MC540 and PI, respectively.

\section{Assessment of DNA degradation}

The TdT-dependent dUTP-biotin nick end-labeling (TUNEL) assay was used to detect DNA degradation. Cells were harvested and washed with PBS containing $2 \%$ FCS and $0.1 \%$ sodium azide (PBSWB). Cells were fixed for $5 \mathrm{~min}$ at room temperature in $2 \%$ paraformaldehyde, washed in PBS-WB and permeabilized for 2 min at $4{ }^{\circ} \mathrm{C}$ with $0.1 \%$ Triton $\mathrm{X}-100,0.1 \%$ sodium citrate, $\mathrm{pH} 7.4$. After three washings in PBS-WB, the samples were resuspended in the TUNEL reaction mixture containing $80 \mu \mathrm{M}$ ATP (Pharmacia, Uppsala, Sweden), $4 \mu \mathrm{M}$ biotin-conjugated dUTP (Boehringer Mannheim, Laval,
QC, Canada), and $7.5 \mathrm{U}$ of terminal deoxynucleotidyl transferase (Pharmacia), and incubated for $1 \mathrm{~h}$ at $37^{\circ} \mathrm{C}$. Incorporation of dUTPbiotin into degraded DNA was revealed by incubating the cells for $1 \mathrm{~h}$ at $4^{\circ} \mathrm{C}$ with streptavidin-conjugated-phycoerythrin (Life Technologies, Burlington, ON, Canada) in PBS-WB. Samples were analyzed on the flow cytometer at $575 \mathrm{~nm}$. Furthermore, nucleosomal fragmentation was detected by gel electrophoresis. A solution of $0.5 \% \mathrm{~N}$ lauroylsarcosine (Sigma-Aldrich), $10 \mathrm{mM}$ EDTA, Tris- $\mathrm{HCl} 50 \mathrm{mM}$, $\mathrm{pH} 8.0$, was used to lyse $10^{6}$ cells. Proteinase K (Sigma-Aldrich) was then added to a final concentration of $0.25 \mathrm{mg} / \mathrm{ml}$, and the samples were incubated overnight at $50^{\circ} \mathrm{C}$. After treatment with $20 \mu \mathrm{g} / \mathrm{ml}$ RNase A (Boehringer Mannheim) for $1 \mathrm{~h}$ at $50^{\circ} \mathrm{C}$, the samples were electrophoresed through a $1.5 \%$ agarose gel and stained with ethidium bromide.

\section{Western blotting}

Treated cells were washed with PBS, and pellets were resuspended in sample buffer $(62.5 \mathrm{mM}$ Tris- $\mathrm{HCl}, \mathrm{pH} 6.8,10 \%$ glycerol, $2 \%$ SDS, bromophenol, 10\% 2-mercaptoethanol), and then boiled for $5 \mathrm{~min}$. Proteins from $1.25-2.5 \times 10^{6} \mathrm{D} 011.10$ cells and thymocytes, respectively, were separated on $15 \%$ SDS-PAGE and transferred onto PVDF membranes (Immobilon, Millipore, Mississauga, ON, Canada). Blots were blocked for $1 \mathrm{~h}$ at room temperature and incubated overnight at $4{ }^{\circ} \mathrm{C}$ with either rabbit polyclonal antibody against caspase$3^{79}$ (gift from Dr. RP Sékaly, Institut de Recherches Cliniques de Montréal, QC, Canada), or rabbit polyclonal antibody against caspase8 (Santa Cruz Biotechnology, Inc., Santa Cruz, CA, USA). Detection was achieved with horseradish peroxidase-conjugated anti-rabbit mAb (Santa Cruz Biotechnology, Inc.), followed by chemiluminescence (SuperSignal ${ }^{\circledR}$ West Pico, Pierce, Rockford, IL, USA).

\section{Caspase activity measurements in extracts and intact cells}

Caspase activity using cellular extracts was measured using ApoAlert ${ }^{\mathbb{R}}$ Caspase 9/6 fluorescent assay kit (Clontech) according to manufacturer's recommendations. Cell extracts (60 $\mu \mathrm{g}$ of proteins) were incubated with $250 \mu \mathrm{M}$ LEHD-aminomethylcoumarin (AMC) peptide substrates. The fluorescence of free AMC, generated as a result of cleavage of the substrate, was monitored over time with a Cytofluor $^{\circledR}$ fluorometer (PerSeptive Biosystems, Foster City, CA, USA). Fluorometric detection of LEHD-AMC is performed using excitation and emission wavelengths of 380 and $460 \mathrm{~nm}$, respectively. Caspase activity using intact cells was measured using either Caspa Tag ${ }^{(i i}$ Caspase 3 or Caspa Tag ${ }^{(i i}$ Caspase 9 activity kits from Intergen Co. (Manhattanville Road, NY, USA). Treated cells were incubated with fluorochrome-labeled inhibitors of caspases (fam-DEVD-fmk or fam-LEHD-fmk) for $1 \mathrm{~h}$ at $37^{\circ} \mathrm{C}$ under $5 \% \mathrm{CO}_{2}$. Cells were washed and resuspended in $400 \mu \mathrm{l}$ wash buffer before flow cytometric analysis at $525 \mathrm{~nm}$.

\section{Acknowledgements}

This work was jointly supported by PROCREA BioSciences Inc. and Medical Research Council of Canada (MT-4264, Dr. S Pande; MT-12637, Dr. P Hugo). F Philippoussis is a recipient of a studentship from FRSQ/ FCAR. We thank M Pagé for excellent technical assistance and Drs. P Jolicoeur, B Massie, and R-P Sékaly for sharing of their reagents. We are grateful to Drs. LM Obeid, M Prentki, G Sauvageau and D Giannacopoulos for critically reviewing the manuscript. 


\section{References}

1. Thompson CB (1995) Apoptosis in the pathogenesis and treatment of disease. Science 267: 1456-1462

2. Penninger JM and Kroemer G (1998) Molecular and cellular mechanisms of $T$ lymphocyte apoptosis. Adv. Immunol. 68: 51-144

3. Ashkenazi A and Dixit VM (1998) Death receptors: signaling and modulation. Science 281: $1305-1308$

4. Krammer PH (2000) CD95's deadly mission in the immune system. Nature 407: $789-795$

5. Nagata S and Golstein P (1995) The Fas death factor. Science 267: 1449-1456

6. Lesage S, Steff AM, Philippoussis F, Page M, TropS, Mateo V and Hugo P (1997) CD4+ CD8+ thymocytes are preferentially induced to die following CD45 crosslinking, through a novel apoptotic pathway. J. Immunol. 159: 4762-4771

7. Wyllie $A H(1980)$ Glucocorticoid-induced thymocyte apoptosis is associated with endogenous endonuclease activation. Nature 284: 555-556

8. Lowe SW, Schmitt EM, Smith SW, Osborne BA and Jacks T (1993) p53 is required for radiation-induced apoptosis in mouse thymocytes. Nature 362 : 847-849

9. Yin Y, Terauchi Y, Solomon GG, Aizawa S, Rangarajan PN, Yazaki Y, Kadowak Tand BarrettJC (1998) Involvement of $p 85$ in p53-dependent apoptotic response to oxidative stress. Nature 391: 707-710

10. Evan G and Littlewood T (1998) A matter of life and cell death. Science 281: 1317-1322

11. Rich T, Allen RL and Wyllie AH (2000) Defying death after DNA change. Nature 407: 777-783

12. Hannun YA and Luberto $C$ (2000) Ceramide in the eukaryotic stress response. Trends Cell Biol. 10: 73-80

13. Mathias S, Pena LA and Kolesnick RN (1998) Signal transduction of stress via ceramide. Biochem. J. 335 (Pt 3): 465-480

14. Obeid LM, Linardic CM, Karolak LA and Hannun YA (1993) Programmed cell death induced by ceramide. Science 259: 1769-1771

15. Sweeney EA, Sakakura C, Shirahama T, Masamune A, Ohta H, Hakomori S and Igarashi Y (1996) Sphingosine and its methylated derivative N,N-dimethylsphingosine (DMS) induce apoptosis in a variety of human cancer cell lines. Int. J. Cancer 66: 358-366

16. De Maria R, Lenti L, Malisan F, d'Agostino F, Tomassini B, Zeuner A, Rippo MR and Testi $R$ (1997) Requirement for GD3 ganglioside in CD95- and ceramideinduced apoptosis. Science 277: $1652-1655$

17. Mollinedo F, Martinez-Dalmau R and Modolell M (1993) Early and selective induction of apoptosis in human leukemic cells by the alkyl-lysophospholipid ET18-OCH3. Biochem. Biophys. Res. Commun. 192: 603-609

18. Mollinedo F, Fernandez-Luna JL, Gajate C, Martin-Martin B, Benito A, MartinezDalmau R and Modolell M (1997) Selective induction of apoptosis in cancer cells by the ether lipid ET-18-OCH3 (Edelfosine): molecular structure requirements, cellular uptake, and protection by Bcl-2 and Bcl-X(L). Cancer Res. 57: 13201328

19. Heerdt BG, Houston MA, Anthony GM and Augenlicht LH (1999) Initiation of growth arrest and apoptosis of MCF-7 mammary carcinoma cells by tributyrin, a triglyceride analogue of the short-chain fatty acid butyrate, is associated with mitochondrial activity. Cancer Res. 59: 1584-1591

20. Holtsberg FW, Steiner MR, Keller JN, Mark RJ, Mattson MP and Steiner SM (1998) Lysophosphatidic acid induces necrosis and apoptosis in hippocampal neurons. J Neurochem. 70: 66-76

21. Holtsberg FW, Steiner MR, Bruce-Keller AJ, Keller JN, Mattson MP, Moyers JC and Steiner SM (1998) Lysophosphatidic acid and apoptosis of nerve growth factor-differentiated PC12 cells. J. Neurosci. Res. 53: 685-696

22. Goetzl EJ and An S (1998) Diversity of cellular receptors and functions for the lysophospholipid growth factors lysophosphatidic acid and sphingosine 1 phosphate. FASEB J. 12: 1589-1598

23. An S (2000) Molecular identification and characterization of $G$ protein-coupled receptors for lysophosphatidic acid and sphingosine 1-phosphate. Ann. NY Acad. Sci. 905: 25-33

24. Matsuda LA, LolaitSJ, Brownstein MJ, Young AC andBonner TI (1990) Structure of a cannabinoid receptor and functional expression of the cloned cDNA. Nature 346: $561-564$

25. Munro S, Thomas KL and Abu-Shaar M (1993) Molecular characterization of a peripheral receptor for cannabinoids. Nature 365: 61-65
26. Devane WA, Dysarz FA, Johnson MR, Melvin LS and Howlett AC (1988) Determination and characterization of a cannabinoid receptor in rat brain. Mol. Pharmacol. 34: 605-613

27. Devane WA, Hanus L, Breuer A, Pertwee RG, Stevenson LA, Griffin G, Gibson D, Mandelbaum A, Etinger A and Mechoulam R (1992) Isolation and structure of a brain constituent that binds to the cannabinoid receptor. Science 258: $1946-$ 1949

28. Sugiura T, Kondo S, Sukagawa A, Nakane S, Shinoda A, Itoh K, Yamashita A and Waku K (1995) 2-Arachidonoylglycerol: a possible endogenous cannabinoid receptor ligand in brain. Biochem. Biophys. Res. Commun. 215: 89-97

29. Mechoulam R, Ben-Shabat S, Hanus L, Ligumsky M, Kaminski NE, Schatz AR, Gopher A, Almog S, Martin BR and Compton DR (1995) Identification of an endogenous 2-monoglyceride, present in canine gut, that binds to cannabinoid receptors. Biochem. Pharmacol. 50: 83-90

30. Maccarrone M, Lorenzon T, Bari M, Melino G and Finazzi-Agro A (2000) Anandamide induces apoptosis in human cells via vanilloid receptors. Evidence for a protective role of cannabinoid receptors. J. Biol. Chem. 275: 31938-31945

31. Schwarz H, Blanco FJ and Lotz M (1994) Anadamide, an endogenous cannabinoid receptor agonist inhibits lymphocyte proliferation and induces apoptosis. J. Neuroimmunol. 55: 107-115

32. Sarker KP, Obara S, Nakata M, Kitajima I and Maruyama I (2000) Anandamide induces apoptosis of PC-12 cells: involvement of superoxide and caspase-3. FEBS Lett. 472: $39-44$

33. Sanchez C, Galve-Roperh I, Canova C, BrachetP and Guzman M (1998) Delta9tetrahydrocannabinol induces apoptosis in C6 glioma cells. FEBS Lett. 436: 6 10

34. Chan GC, Hinds TR, Impey S and Storm DR (1998) Hippocampal neurotoxicity of Delta9-tetrahydrocannabinol. J. Neurosci. 18: 5322-5332

35. Ruiz L, Miguel A and Diaz-Laviada I (1999) Delta9-tetrahydrocannabinol induces apoptosis in human prostate PC-3 cells via a receptor-independent mechanism. FEBS Lett. 458: 400-404

36. Galve-Roperh I, Sanchez C, Cortes ML, del Pulgar TG, Izquierdo M and Guzman M (2000) Anti-tumoral action of cannabinoids: involvement of sustained ceramide accumulation and extracellular signal-regulated kinase activation. Nat. Med. 6: 313-319

37. Kondo S, Kondo H, Nakane S, Kodaka T, Tokumura A, Waku K and Sugiura T (1998) 2-Arachidonoylglycerol, an endogenous cannabinoid receptor agonist: identification as one of the major species of monoacylglycerols in various rat tissues, and evidence for its generation through CA2+-dependent and -independent mechanisms. FEBS Lett. 429: 152-156

38. Fielding BA, Humphreys SM, Allman RF and Frayn KN (1993) Mono-, di- and triacylglycerol concentrations in human plasma: effects of heparin injection and of a high-fat meal. Clin. Chim. Acta 216: 167-173

39. Tigyi G, Hong L, Yakubu M, Parfenova H, Shibata M and Leffler CW (1995) Lysophosphatidic acid alters cerebrovascular reactivity in piglets. Am. J. Physiol. 268: $\mathrm{H} 2048-\mathrm{H} 2055$

40. Bavbek M, Nietgen GW, Bogaev C, Fineman MB, Polin R, Chen ZF, Lee KS, Kassell NF and Durieux ME (1996) Increased lysophosphatidate levels in CSF after subarachnoid hemorrhage. Soc. Neurosci. Abstr. 22: 1566

41. McConkey DJ and Orrenius S (1997) The role of calcium in the regulation of apoptosis. Biochem. Biophys. Res. Commun. 239: 357-366

42. Krebs J (1998) The role of calcium in apoptosis. Biometals 11: $375-382$

43. Lohmeyer M and Workman $P$ (1993) The role of intracellular free calcium mobilization in the mechanism of action of antitumour ether lipids SRI 62-834 and ET18-OMe. Biochem. Pharmacol. 45: 77-86

44. Liu G, Kleine L and Herbert RL (1999) Advances in the signal transduction of ceramide and related sphingolipids. Crit. Rev. Clin. Lab. Sci. 36: 511-573

45. Ashwell JD, Lu FW and Vacchio MS (2000) Glucocorticoids in T cell development and function. Annu. Rev. Immunol. 18: 309-345

46. Dhein J, Walczak H, Baumler C, Debatin KM and Krammer PH (1995) Autocrine T-cell suicide mediated by APO-1/(Fas/CD95). Nature 373: 438-441

47. Brunner T, Mogil RJ, LaFace D, Yoo NJ, Mahboubi A, Echeverri F, Martin SJ, Force WR, Lynch DH, Ware CF and Green DR (1995) Cell-autonomous Fas (CD95)/Fas-ligand interaction mediates activation-induced apoptosis in T-cell hybridomas. Nature 373: 441-444

48. Ju ST, Panka DJ, Cui H, Ettinger R, el-Khatib M, Sherr DH, Stanger BZ and Marshak-Rothstein A (1995) Fas(CD95)/FasL interactions required for programmed cell death after T-cell activation. Nature 373: 444-448 
49. Gross A, McDonnell JM and Korsmeyer SJ (1999) BCL-2 family members and the mitochondria in apoptosis. Genes Dev. 13: 1899-1911

50. Vander HM and Thompson CB (1999) Bcl-2 proteins: regulators of apoptosis or of mitochondrial homeostasis? Nat. Cell Biol. 1: E209-E216

51. Mosser DD, Caron AW, Bourget L, Denis-Larose C and Massie B (1997) Role of the human heat shock protein hsp70 in protection against stress-induced apoptosis. Mol. Cell. Biol. 17: 5317-5327

52. Basu S, Bayoumy S, Zhang Y, Lozano J and Kolesnick R (1998) BAD enables ceramide to signal apoptosis via Ras and Raf-1. J. Biol. Chem. 273: 3041930426

53. de Vries JE, Vork MM, Roemen TH, de Jong YF, Cleutjens JP, van der Vusse GJ and van Bilsen M (1997) Saturated but no mono-unsaturated fatty acids induce apoptotic cell death in neonatal rat ventricular myocytes. J. Lipid Res. 38: 1384 1394

54. de Pablo MA, Susin SA, Jacotot E, Larochette N, Costantini L, Ravagnan L, Zamzami N and Kroemer G (1999) Palmitate induces apoptosis via a direct effect on mitochondria. Apoptosis 4: 81-87

55. Cao Y, Pearman AT, Zimmerman GA, McIntyre TM and Prescott SM (2000) Intracellular unesterified arachidonic acid signals apoptosis. Proc. Natl. Acad. Sci. USA 97: 11280-11285

56. Jiang S, Chow SC, Nicotera P and Orrenius S (1994) Intracellular Ca2+ signals activate apoptosis in thymocytes: studies using the $\mathrm{Ca}(2+)$-ATPase inhibitor thapsigargin. Exp. Cell Res. 212: 84-92

57. KaiserN and Edelman IS (1977) Calcium dependence of glucocorticoid-induced lymphocytolysis. Proc. Natl. Acad.Sci. USA 74: 638-642

58. McConkey DJ, Nicotera $P$, Hartzell $P$, Bellomo G, Wyllie AH and Orrenius $S$ (1989) Glucocorticoids activate a suicide process in thymocytes through an elevation of cytosolic Ca2+ concentration. Arch. Biochem. Biophys. 269: 365370

59. Lennon SV, Kilfeather SA, Hallett MB, Campbell AK and Cotter TG (1992) Elevations in cytosolic free $\mathrm{Ca} 2+$ are not required to trigger apoptosis in human leukaemia cells. Clin. Exp. Immunol. 87: 465-471

60. Macho A, Calzado MA, Munoz-Blanco J, Gomez-Diaz C, Gajate C, Mollinedo F, Navas P and Munoz E (1999) Selective induction of apoptosis by capsaicin in transformed cells: the role of reactive oxygen species and calcium. Cell Death Differ. 6: $155-165$

61. Nicotera P and Orrenius S (1998) The role of calcium in apoptosis. Cell Calcium 23: $173-180$

62. Alonso MT, Gajate C, Mollinedo F, Modolell M, Alvarez J and Garcia-Sancho J (1997) Dissociation of the effects of the antitumour ether lipid ET-18-OCH3 on cytosolic calcium and on apoptosis. Br. J. Pharmacol. 121: 1364-1368

63. Duncan R, Ferruti P, Sgouras D, Tuboku-Metzger A, Ranucci E and Bignotti F (1994) A polymer-Triton X-100 conjugate capable of PH-dependent red blood cell lysis: a model system illustrating the possibility of drug delivery within acidic intracellular compartments. J. Drug Target 2: 341-347

64. Borner MM, Schneider E, Pirnia F, Sartor O, Trepel JB and Myers CE (1994) The detergent Triton X-100 induces a death pattern in human carcinoma cell lines that resembles cytotoxic lymphocyte-induced apoptosis. FEBS Lett. 353: 129-132
65. Marchetti C, Migliorati G, Moraca R, Riccardi C, Nicoletti I, Fabiani R, Mastgrandrea V and Morozzi G (1997) Deoxycholic acid and SCFA-induced apoptosis in the human tumor cell-line HT-29 and possible mechanisms. Cancer Lett. 114: 97-99

66. Marchetti MC, Migliorati G, Moraca R, Riccardi C, Nicoletti I, Fabiani R, Mastrandrea V and Morozzi G (1997) Possible mechanisms involved in apoptosis of colon tumor cell lines induced by deoxycholic acid, short-chain fatty acids, and their mixtures. Nutr. Cancer 28: 74-80

67. Strupp W, Weidinger G, Scheller C, Ehret R, Ohnimus $H$, Girschick $H$, Tas $P$, Flory E, Heinkelein M and Jassoy C (2000) Treatment of cells with detergent activates caspases and induces apoptotic cell death. J. Membr. Biol. 175: 181 189

68. Brindley DN and Waggoner DW (1996) Phosphatidate phosphohydrolase and signal transduction. Chem. Phys. Lipids 80: $45-57$

69. Prescott SM, Zimmerman GA and McIntyre TM (1990) Platelet-activating factor. J. Biol. Chem. 265: 17381-17384

70. Venkataraman $\mathrm{K}$ and Futerman $\mathrm{AH}(2000)$ Ceramide as a second messenger: sticky solutions to sticky problems. Trends Cell Biol. 10: 408-412

71. Kelley EE, Modest EJ and Burns CP (1993) Unidirectional membrane uptake of the ether lipid antineoplastic agent edelfosine by L1210 cells. Biochem. Pharmacol. 45: 2435-2439

72. Bazill GW and Dexter TM (1990) Role of endocytosis in the action of ether lipids on WEHI-3B, HL60, and FDCP-mix A4 cells. Cancer Res. 50: 7505-7512

73. Berdel WE, Andreesen R and Munder PG (1985) Synthetic alkyl-phospholipid analogs; A new class of antitumor agents. In Phospholipids and cellular regulation, Kuo JF, eds (Boca Raton, FL: CRC Press, Inc.), pp. 41-73

74. Kato A, Ando K, Suzuki S, Tamura G and Arima K (1969) Antitumor activity of monoglycerides and other esters of fatty acids. J. Antibiot. (Tokyo) 22: 83-84

75. Haskins K, Kubo R, White J, Pigeon M, Kappler J and Marrack P (1983) The major histocompatibility complex-restricted antigen receptor on T cells. I. Isolation with a monoclonal antibody. J. Exp. Med. 157: 1149-1169

76. Kubo RT, Born W, Kappler JW, Marrack P and Pigeon M (1989) Characterization of a monoclonal antibody which detects all murine alpha beta T cell receptors. J. Immunol. 142: 2736-2742

77. Rijkers GT, Justement LB, Griffioen AW and Cambier JC (1990) Improved method for measuring intracellular $\mathrm{Ca}++$ with fluo-3. Cytometry 11: 923-927

78. Martin SJ, Reutelingsperger CP, McGahon AJ, Rader JA, van Schie RC, LaFace DM and Green DR (1995) Early redistribution of plasma membrane phosphatidylserine is a general feature of apoptosis regardless of the initiating stimulus: inhibition by overexpression of Bcl-2 and Abl. J. Exp. Med. 182: $1545-$ 1556

79. Alam A, Braun MY, Hartgers F, Lesage S, Cohen L, Hugo P, Denis F and Sekaly RP (1997) Specific activation of the cysteine protease CPP32 during the negative selection of T cells in the thymus. J. Exp. Med. 186: 1503-1512 